Ә OPEN ACCESS

\title{
The influence of achievement motivation on learning achievement of Introduction to Accounting course
}

\author{
Reyna Karlina ${ }^{1}$ \\ Yon Rizal ${ }^{2}$ (B) \\ Pujiati $^{3}$ (i) \\ Albet Maydiantoro ${ }^{4}$ \\ ${ }^{1-4}$ Economic Education, University of Lampung, Bandar Lampung, Indonesia
}

\begin{abstract}
This study aims to determine the influence of achievement motivation variable on learning achievement in Introduction to Accounting course of Economic Education students at the University of Lampung. The study employed a descriptive method using an ex-post facto approach and a survey with a population of 170 . The research sample was determined through a purposive sampling with a total of 119 respondents. The data collected through a questionnaire were processed using SPSS to run partial hypothesis testing through t-test and simultaneous F-test. The results of this study indicate that there is an influence of achievement motivation on learning achievement in Introduction to Accounting course among Economic Education students at the University of Lampung.
\end{abstract}

\section{KEYWORDS}

Learning achievement; introduction to accounting; motivation; economic education

Received: 31 January 2021 Accepted: 2 February 2021 Published: 4 February 2021

\section{Introduction}

In the current era of globalization, there are many problems that must be anticipated (Cosgrove \& Loucks, 2015; Peters, 2015). One of which is by developing the potential of human resources through improving the quality of education. Education is a conscious effort made by the government to develop human potential through teaching, training, and research activities (Fenwick, Edwards, \& Sawchuk, 2015; Taufik, 2019). Having quality education, it is likely that quality human resources will be created and have high competitiveness as the main capital in national development. Without education a country will not improve and develop (Franita, 2016; Umam, 2020; Zhang, Wang, Yang, \& Wang, 2020). That is what the government and society pay attention to prioritizing education. 
Education is closely related to learning. Learning is an activity to obtain a myriad of knowledge in order to get the desired achievement in the learning process (Backhouse, Fitzpatrick, Hutchinson, Thandi, \& Keenan, 2017; Behzadnia, Adachi, Deci, Mohammadzadeh, \& Exercise, 2018; Gasong, 2018). Every one's achievements are not the same. Many people study hard but get nothing, only fail after failure. Basically, students who take part in learning definitely want a high achievement, but in fact there are still students who fail to get the desired achievement.

Introduction to Accounting course is one of the subjects that affects other courses and become a scourge for students taking these courses (Haryono \& Fadhilah, 2017; Sakdiah \& Silalahi, 2017). Being the only subject that has four credits makes all students expect satisfying results or achievements. This Introduction to Accounting course is also a prerequisite course for taking other accounting courses so that the achievements obtained by students in this course are considered crucial and have a major effect on the acquisition of their Grade Point Average (GPA) in the semester being taken.

An internal factor that has an impact on learning achievement in the next accounting courses is achievement motivation (Astuti, 2019; Dafouz \& Camacho-Miñano, 2016; Kumar, Zusho, \& Bondie, 2018; Tawakal, 2018). Achievement motivation is something that comes from within a person in the form of encouragement to achieve success from an achievement. Motivation of achievement also means the same as personal efforts to raise the level of persistence and a sense of enthusiasm with the implementation of the activity (Andriani, Kesumawati, \& Kristiawan, 2018; Pujiastuti, 2015; Purnamaningsih, 2019).

Based on preliminary data, it is evident that students of Economic Education have low achievement motivation in attending the Introduction to Accounting course. Most of them, about 51.64\% (28 students) and 24.74\% (14 students) stated that they have moderate achievement motivation. Less than half of them, 23.62\% (13 students) stated that they have high achievement motivation in the course. Hayati \& Dewi (2018); Magnano, Craparo, \& Paolillo (2016) explained that motivation for achievement is something that changes a person, the sign is by the emergence of a feeling of achievement, by realizing a direction of achievement, a person is intended to carry out activities that are in line with what is needed. Therefore, this study aims to find out the influence of achievement motivation on Llearning achievement in Introduction to Accounting Course of Economics Education Students at the University of Lampung.

\section{Literature review}

\section{Learning achievement}

Achievement refers to values of efforts that have been achieved by students in the learning process. Changes in person's knowledge, whether increasing or decreasing, are indicated by the level of achievement they have achieved (Morgan, Farkas, Hillemeier, \& Maczuga, 2016; Nisa, 2017; Stroh, 2015; Syaparuddin, Meldianus, \& Elihami, 2020). This is in line with opinions of Andersson \& Palm (2017); Astuti (2015); Bal-Taştan et al. (2018); Siagian (2015) that say that achievement is a change in students' behaviour after the teaching and learning process is carried out. Learning is acquisition of new knowledge and skills. Meanwhile, according to Castro et al. (2015); Raslimin (ㅁ18); Su \& Cheng (2015); Susilowati (2017), learning achievement is the result of learning process achievement carried out by means of learning activities and the form of achievement that is considered from the acquisition of tests.

There are things that need to be considered in achieving learning achievement in Introduction to Accounting course. Several factors are needed to be taken into account including ability and effort, intellectual skills, high school grades, college grades, emotional skills, and learning environment (Nyström, Jackson, \& Salminen Karlsson, 2019; Oetary, 2018; Petersen \& Hyde, 2017).

Šavija \& Luković (2016); Weiner (2018); Yuliani \& Saragih (2015) stated that ability and effort are means used to gain a concrete understanding of an Introduction to Accounting course that the abilities obtained are not only to memorize the material but also to comprehend very well. Introduction to Accounting course requires more effort in the learning process than other 
subjects, this is because the course is the basic before taking more complex accounting courses (Gupta, Goul, \& Dinter, 2015; Oetary, 2018; Sari, 2018).

According to Cilateral, Wright, Smith, McMahon, \& Kraiss (2015); Han \& Li (2015); Nafiati (2015), intellectual skill is an ability shown by students about the intellectual operations they can perform. The efforts made to support students to have the ability and effort as well as good intellectual skills against the Introduction to Accounting can be seen from their high school grades or achievement when they were in high school.

The accomplishment of introduction to Accounting learning achievement is also influenced by emotional skills and learning environment (Costa \& Faria, 2015; Schenke, Lam, Conley, \& Karabenick, 2015). This is an ability to feel, understand, and apply emotional power and sense effectively as a source of energy, information, connection, and influence (Pasek, 2017; Saputra et al., 2017; Tyng, Amin, Saad, \& Malik, 2017). All of these factors should take place in a conducive learning environment.

Based on statements above, learning achievement is an tasks' assessment that reflects a change in behavior experienced by students as a result of learning that has been followed through learning programs in higher education. Learning achievement is the achievement achieved by students which are manifested in the form of values from lecturers to students in the form of qualitative or quantitative grades within a certain time.

\section{Achievement motivation}

All activities carried out in human life have a direction and hope. Students also have hopes for success in their studies. Motivation is something in the form of mobilizing student personalities to carry out activities that support learning success. Motivation comes from the word "motive" or "motion" which is derived from the English language which means booster (Afrinaldi, 2019; Prayogo, 2016; Wilhelms, Henkel, \& Falk, 2017).

There are not much different from the previous opinion. Indah (2019) explained that achievement motivation is something that changes personal energy, the sign which appears in feelings and achievements. It is desired as a form of achievement that appears, to carry out learning activities in accordance with what is needed. Meanwhile, according to Brunstein \& Heckhausen (2018); Khiari (2017), achievement motivation is a physiological or mental state needed on a personal basis, to become a driving force for carrying out activities, with certain achievements. According to Bagianto \& Yuniati (2018); Rahayu (2018), achievement motivation is desirable without much impact from social influence but intended for personal satisfaction only.

Based on these assumptions, achievement motivation is what becomes a personal impetus to achieve a goal. It becomes a crucial factor, the most important in teaching. Sardiman (2000) states that there are several forms and ways to foster motivation in learning activities to achieve good learning achievement, namely by 1) giving grades, the grades in the form of learning outcome' grades; 2) giving gifts, this gift can be in the form of morality and materiality; 3) competition, which can indirectly create an impetus in oneself to study harder in order to get the achievements desired by someone who is studying; 4) ego-involvement, the competition will make one's ego to learn higher as well as involvement to achieve high learning achievement; 5) giving tests, which can train students to remember, answer questions and sharpen their learning abilities; 6) knowing the results, after following a test, releasing its results immediately will increase students' motivation to practice continuously; 7) praise, which is very helpful in increasing student motivation after knowing the results of tests that have been done, whether the results are satisfiying or not; 8) punishment, when they have not succeeded in getting their desired achievement, punishment can give students a separate lash to be more active in studying; 9) desire to learn, students do not to mind to begin a learning process; 10) interest, student interest in certain subjects is definitely needed in fostering achievement motivation.

The characteristics of students who have a low achievement motivation level, namely choosing too easy tasks, do not like giving feedback, having less responsibility for the tasks they are doing, enjoying structured work (Brunstein \& Heckhausen, 2018; De Castella \& Byrne, 2015). 
The existence of encouragement from within a person to learn is a form of motivation. Achievement motivation means that a student has a willingness and encouragement to move or direct energy to carry out activities that support the realization of goals in learning, and are enthusiastic in facing all their challenges and obstacles to achieve maximum learning achievement (Andriani et al., 2018; Partovi \& Razavi, 2019; Rohayati, 2015; Suo \& Hou, 2017). The high achievement is influenced by the high achievement motivation that is owned.

\section{Methods}

This research is descriptive in nature using an ex-post facto approach and a survey. A descriptive method can be defined as research that aims to describe the state of the object or research subject (a person, institution, society, etc.) at the present time based on visible facts or as they are. The purpose of this research was verification, which was to determine the level of influence of variables in a certain condition.

The data collected in this study were based on existing data at the research site so that they used the ex-post facto and survey approaches. A research with the ex post facto approach is a research that examines an event that has occurred by tracing back to find out what factors caused the incident.

Survey research is research conducted on large or few populations, but the data to be studied were data from a sample taken from that population so that relative incidents, distribution, and relationships between sociological and psychological variables are found.

\section{Participants}

The population in this study were six classes of Economic Education Students class of 2016-2018 of the Faculty of Teacher Training and Education, University of Lampung, which were included in the category determined by the researcher with a total of 170 students. In this study, the determination of the size of the sample taken was calculated using the Slovin formula totaling 119 students. The technique used to determine the size of the sample in each class was carried out with proportional allocation so that the samples taken in this study were more proportional.

\section{Instruments}

This study adopted a questionnaire for data collection as primary data. Other instruments, e.g., observation and documentation, were used to obtain supporting data that was carried out during the preliminary research. Prior distribution to the respondens, the questionnaire received a pilot testing for validity and reliability, so that the instrument was correct and valid, in accordance with reality, and could provide a picture of the data correctly in accordance with the actual reality or situation with high level of confidence.

\section{Data analysis}

To measure the influence of the independent variable on the dependent variable and also to measure the closeness of the relationship between $\mathrm{X}$ and $\mathrm{Y}$, a simple regression analysis was used, namely a model to test the effect of the independent variable on the dependent variable, where the independent variable was only one. The use of simple linear regression in this study was to predict the dependent variable $(Y)$ when the independent variable $(\mathrm{X})$ was known. Simple regression was based on a functional or causal relationship or an independent variable with one dependent variable.

\section{Results}

\section{Achievement Motivation $(X)$}

Data on achievement motivation were obtained through distributing questionnaires to a sample of 119 respondents consisting of 20 question items. Each question consists of a score of 1 
to 7 with the highest score of 112 and the lowest of 77 . The calculation of the frequency distribution is as follows:
a. Range
$=112-77=35$
b. Number of classes
$=1+3,3 \log 119=1+3,3(2,076)=7,849$ (rounded to 8$)$
c. Class length
$=4.375$ (rounded to 4$)$

Table 1. Frequency distribution of achievement motivation variables

\begin{tabular}{cccc}
\hline No. & Interval Class & Frequency & Percentage (\%) \\
\hline 1 & $77-80$ & 7 & 5.88 \\
2 & $81-84$ & 15 & 12.61 \\
3 & $85-88$ & 19 & 15.97 \\
4 & $89-92$ & 36 & 30.25 \\
5 & $93-96$ & 26 & 21.85 \\
6 & $97-100$ & 13 & 10.92 \\
7 & $101-104$ & 2 & 1.68 \\
8 & $105-108$ & 0 & 0.00 \\
9 & $109-112$ & 1 & 0.84 \\
& total & $\mathbf{1 1 9}$ & $\mathbf{1 0 0}$ \\
\hline
\end{tabular}

Source: Data Processing Results (2020)

Based on Table 1 above, it can be seen that the highest frequency is in the 89-92 interval class, namely 36 respondents (30.25\%) and the lowest frequency is in the 105-108 interval class, namely there are no respondents (0\%). Based on the tendency of the achievement motivation variable into three categories, namely high, medium and low, the following calculations are carried out.

1. Grade range $(\mathrm{R}) \quad$ = largest score - smallest score

$$
\begin{aligned}
& =112-77 \\
& =35
\end{aligned}
$$

2. Determine the length of the class interval

Class length $\quad=11.667$ (round to 12 )

Based on the tendency of the achievement motivation variable into three categories, namely high, medium, and low, the following calculations have been made.

Table 2. Category of achievement motivation

\begin{tabular}{ccccc}
\hline No. & Interval Class & Frequency & Percentage (\%) & Category \\
\hline 1 & $101-112$ & 3 & 2.52 & High \\
2 & $89-100$ & 75 & 63.03 & Moderate \\
3 & $77-88$ & 41 & 34.45 & Low \\
& Total & 119 & $\mathbf{1 0 0}$ & \\
\hline
\end{tabular}

Source: Data Processing Results (2020)

Based on Table 2 above, it can be seen that the achievement motivation of Economic Education students of FKIP, University of Lampung in 2019/2020 academic year is in the medium category, namely as many as 68 respondents with a percentage of $57.14 \%$. It can be interpreted that some of them are influenced by achievement motivation. High learning achievement can be achieved if learning activities are fully supported by achievement motivation as a driving force within oneself.

Masni (2017); Sari (2018); Wibowo \& Marzuki (2015) state that in learning activities motivation can be said to be the overall driving force within students that gives rise to learning activities, which ensures the continuity of learning activities and which provides a direction of learning activities so that the goals desired by the learning subjects can be achieved, whereas according to (Lailiana \& Handayani, 2017; Susanto, 2018) "achievement motivation is a tendency to achieve success or goals to carry out activities that lead to success or failure. students who 
have high achievement motivation tend to experience success in doing study assignments in the world of lectures".

\section{Learning Achievement (Y)}

Data on learning achievement were obtained through the values of the highest score of 72 and the lowest of 50 . The calculation of the frequency distribution is as follows.
a. Range
$=72-50=22$
b. Number of classes
$=1+3,3 \log 119=1+3,3(2,076)=7,849$ (rounded to 8$)$
c. Class length
$=228=2.75$ (rounded to 3 )

\section{Discussion}

Based on the results of the analysis, it can be seen that there is an influence achievement motivation on learning achievement in Introduction to Accounting course. This can be proven by the hypothesis which shows that the $\mathrm{t}_{\text {count }}$ coefficient is 7.496 and $\mathrm{t}_{\text {table }}$ with $\mathrm{dk}=117$ at $\alpha=0.05$ for 1.658 , thus $\mathrm{t}_{\text {count }}>\mathrm{t}_{\text {table }}$ or $7.496>1.658$ which means that $\mathrm{H}_{0}$ is rejected and $\mathrm{H}_{1}$ is accepted, or in other words, the factor achievement motivation effect on learning achievement in Introduction to Accounting course. These results suggest that the higher the influence of achievement motivation is, the higher the student achievement in Introduction to Accounting course will be.

The level of partial relationship between achievement motivation and learning achievement is 0.573 , including a moderate level of relationship with a determination level of (0.573) $2 \times 100=32.83 \%$, which means that learning achievement can be partially influenced by the achievement motivation variable of $32.83 \%$ the rest by other variables.

The results of this study are in line with research conducted by Sri Astuti (2011, p. 78) that there is an effect of achievement motivation on learning achievement in the subject of accounting for students of.

According to Brunstein \& Heckhausen (2018); Masni (2017), motivation can be interpreted as a driving force from within and within the subject to carry out certain activities in order to achieve a goal, while according to (Hayati \& Dewi, 2018; Lailiana \& Handayani, 2017; Rohayati, 2015; Sardiman, 2000), motivation is formulated as a process that determines levels of activity, intensity, consistency, and general direction of human behavior, and is a complex concept related to other concepts such as interests, self-concept, attitudes and so on.

Based on this explanation it is proved that achievement motivation is one of the influencing factors on learning achievement in Introduction to Accounting course of Economics Education students class of 2016-2018 at the Faculty of Teacher Training and Education, University of Lampung.

\section{Conclusion}

To obtain satisfactory accounting introduction learning achievements, students should get used to taking time to practice working on accounting introduction tasks in books or handbooks as a medium for transformation and dissemination of knowledge because by having learning habits there will be a complex thinking process, consisting of a number of activities, such as the skill of understanding written words or sentences, interpreting, and reflecting well on accounting introduction material so that it can indirectly foster motivation to excel. The results of this study can be used as a future researchers' reference for their research success.

\section{Acknowledgments}

We would like to thank those who cannot be mentioned one by one, who have helped this research. Our gratitude goes to parties who have provided intellectual assistance, technical assistance or equipment as well as special materials during the research. 


\section{Funding}

This research did not receive a specific grant from any funding agency in the public, commercial, or non-profit sector.

\section{References}

Afrinaldi. (2019). Correlation of server administration learning outcomes with learning motivation and the use of interactive media for class XII TKJ SMK Negeri 1 Solok. 5 (3), 39.

Andersson, C., \& Palm, T. (2017). The impact of formative assessment on student achievement: A study of the effects of changes to classroom practice after a comprehensive professional development program. 49, 92-102.

Andriani, S., Kesumawati, N., \& Kristiawan, M. (2018). The influence of the transformational leadership and work motivation on teachers performance. 7 (7), 19-29.

Astuti, SIP (2019). the effect of anxiety in facing math tests and achievement motivation on student achievement (in class XI SMK al-Mustaqim susukan 2018/2019 academic year). IAIN salatiga,

Astuti, SP (2015). The effect of initial ability and interest in learning on physics learning achievement. 5 (1).

Backhouse, M., Fitzpatrick, M., Hutchinson, J., Thandi, CS, \& Keenan, I. (2017). Improvements in anatomy knowledge when utilizing a novel cyclical "observe - reflect - draw - edit - repeat"learning process. 10 (1), 7-22.

Bagianto, A., \& Yuniati, Y. (2018). The influence of foster children leadership and motivation on the social welfare of foster children at the Kurnia Asih Orphanage Bandung. 2 (1), 10-29.

Bal-Taştan, S., Davoudi, SMM, Masalimova, AR, Bersanov, AS, Kurbanov, RA, Boiarchuk, AV, \& Pavlushin, AA (2018). The impacts of teacher's efficacy and motivation on student's academic achievement in science education among secondary and high school students. 14 (6), 2353-2366.

Behzadnia, B., Adachi, PJ, Deci, EL, Mohammadzadeh, HJP o. S., \& Exercise. (2018). Associations between students' perceptions of physical education teachers' interpersonal styles and students' wellness, knowledge, performance, and intentions to persist at physical activity: A self-determination theory approach. 39, 10-19.

Brunstein, JC, \& Heckhausen, H. (2018). Achievement motivation. In Motivation and action (pp. 221-304): Springer.

Castro, M., Expósito-Casas, E., López-Martín, E., Lizasoain, L., Navarro-Asencio, E., \& Gaviria, JL (2015). Parental involvement on student academic achievement: A meta-analysis. 14, 33-46.

Cilateral, DF, Wright, R., Smith, CC, McMahon, D., \& Kraiss, K. (2015). Incorporating functional digital literacy skills as part of the curriculum for high school students with intellectual disability. 155-171.

Cosgrove, WJ, \& Loucks, DPJWRR (2015). Water management: Current and future challenges and research directions. 51 (6), 4823-4839.

Costa, A., \& Faria, L. (2015). The impact of emotional intelligence on academic achievement: A longitudinal study in Portuguese secondary school. 37, 38-47.

Dafouz, E., \& Camacho-Miñano, MM (2016). Exploring the impact of English-medium instruction on university student academic achievement: The case of accounting. 44, 57-67.

De Castella, K., \& Byrne, D. (2015). My intelligence may be more malleable than yours: The revised implicit theories of intelligence (self-theory) scale is a better predictor of achievement, motivation, and student disengagement. 30 (3), 245-267.

Fenwick, T., Edwards, R., \& Sawchuk, P. (2015). Emerging approaches to educational research: Tracing the socio-material: Routledge.

Franita, R. (2016). Unemployment analysis in Indonesia. 1 (3), 88-93.

Gasong, D. (2018). Study and study: Deepublish.

Gupta, B., Goul, M., \& Dinter, B. (2015). Business intelligence and big data in higher education: Status of a multi-year model curriculum development effort for business school undergraduates, MS graduates, and MBAs. 36 (1), 23.

Han, Y., \& Li, D. (2015). Effects of intellectual capital on innovative performance: The role of knowledge-based dynamic capability.

Haryono, L., \& Fadhilah, A. (2017). Settings contribution of online learning in helping students understand accounting. 1 (1), 60-67.

Hayati, R., \& Dewi, DP (2018). The correlation between achievement motivation and presentation skills in the English language education students of the Faculty of Teacher Training and Pekalongan University Education. 15.

Indah, ER (2019). Ekonomy Token application to increase a child's learning motivation in Gladak Anyar Pamekasan. UIN Sunan Ampel Surabaya,

Khiari, I. (2017). The influence of learning motivation and self-concept on student achievement of Class VII MTs Abdulloh Bangsongan Sukoanyar Mojo Kab. Kediri for the 2016/2017 school year. IAIN Kediri,

Kumar, R., Zusho, A., \& Bondie, R. (2018). Weaving cultural relevance and achievement motivation into inclusive classroom cultures. 53 (2), 78-96.

Lailiana, NA, \& Handayani, A. (2017). Achievement motivation in terms of commitment to assignments to students. Paper presented at the Proceedings Education and Language International Conference.

Magnano, P., Craparo, G., \& Paolillo, A. (2016). Resilience and emotional intelligence: which role in achievement motivation. 9 (1), 9-20. 
Masni, H. (2017). Strategies to increase student motivation. 5 (1), 34-45.

Morgan, PL, Farkas, G., Hillemeier, MM, \& Maczuga, S. (2016). Science achievement gaps begin very early, persist, and are largely explained by modifiable factors. 45 (1), 18-35.

Nafiati, DA (2015). Factors that affect the learning achievement of introduction accounting courses (empirical study of accounting students in Central Java). Paper presented at the Proceedings of the National Seminar.

Nisa, A. (2017). The influence of parental attention and student interest in learning on social science learning achievement. 2 (1), 1-9.

Nyström, A.-S., Jackson, C., \& Salminen Karlsson, M. (2019). What counts as success? Constructions of achievement in prestigious higher education programs. 34 (4), 465-482.

Oetary, N. (2018). Factors that influence the success and failure of accounting students in introduction accounting courses (empirical study of undergraduate accounting students at the Faculty of Economics, Padang State University). 6 (1).

Partovi, T., \& Razavi, MR (2019). The effect of game-based learning on academic achievement motivation of elementary school students. 68, 101592.

Pasek, NS (2017). The influence of intellectual intelligence on understanding accounting with emotional intelligence and spiritual intelligence as moderating variables. 1 (1).

Peters, MEJWP (2015). Open trade, closed borders immigration in the era of globalization. 67, 114.

Petersen, JL, \& Hyde, JS (2017). Trajectories of self-perceived math ability, utility value and interest across middle school as predictors of high school math performance. 37 (4), 438-456.

Prayogo, A. (2016). The influence of motivation and organizational culture on employee productivity (case study at PT Boogi Avindo, Bogor). 13 (2), 235-256.

Pujiastuti, T. (2015). The influence of student discipline and learning motivation on mathematics learning achievement at MI Kota Salatiga in the 2014/2015 academic year. IAIN Salatiga,

Purnamaningsih, IR (2019). The influence of coaching management and achievement motivation on the achievements of volleyball club silvas athletes, Cijulang district, Pangandaran district. 2 (1), 43-53.

Rahayu, OE (2018). The influence of the condition of broken home parents on students' learning motivation in social studies subjects at SMP Negeri 1 Gondanglegi. Maulana Malik Ibrahim State Islamic University,

Raslimin, WO (2018). The application of attitudes towards Indonesian learning achievement for students at MTsN I Wakatobi. 4 (1), 115-135.

Rohayati, T. (2015). The influence of commitment and achievement motivation on the managerial performance of public elementary school principals in Cicalengka District. 21 (1), 59-68.

Sakdiah, K., \& Silalahi, CAP (2017). The influence of students' perceptions of learning difficulties in accounting on student motivation 1 (1).

Saputra, GW, Rivai, MA, Su'udah, M., Wulandari, SLG, Dewi, TR, \& Fitroh, F. (2017). Effect of information technology on intelligence (intellectual, spiritual, emotional and social) case study: children. 10 (2).

Sardiman, AM (2000). Teaching and learning interaction \& motivation: PT RajaGrafindo Persada.

Sari, I. (2018). Motivation to learn management study program students in mastering English speaking skills. 9 (1), 41-52.

Sari, IP (2018). The influence of learning behavior, lecturer teaching styles, and emotional intelligence on student understanding of introduction accounting courses. 4 (2).

Šavija, B., \& Luković, M. (2016). Carbonation of cement paste: Understanding, challenges, and opportunities. 117, 285-301.

Schenke, K., Lam, AC, Conley, AM, \& Karabenick, SA (2015). Adolescents' help seeking in mathematics classrooms: Relations between achievement and perceived classroom environmental influences over one school year. 41, 133-146.

Siagian, REF (2015). The influence of student interest and study habits on mathematics learning achievement. $2(2)$.

Stroh, DP (2015). Systems thinking for social change: A practical guide to solving complex problems, avoiding unintended consequences, and achieving lasting results: Chelsea Green Publishing.

$\mathrm{Su}, \mathrm{CH}$, \& Cheng, CH (2015). A mobile gamification learning system for improving the learning motivation and achievements. 31 (3), 268-286.

Suo, J., \& Hou, X. (2017). A study on the motivational strategies in college English flipped classroom. 10 (5), 62 67.

Susanto, A. (2018). Guidance and counseling in schools: concepts, theories, and applications: gold.

Susilowati, S. (2017). Development of integrated science teaching materials Islamic values to improve students' attitudes and learning achievement in science. 3 (1), 78-88.

Syaparuddin, S., Meldianus, M., \& Elihami, E. (2020). Active learning strategies in increasing student motivation to learn. 1 (1), 30-41.

Taufik, A. (2019). Perspectives on the development of distance learning systems in Kutai Kartanegara Regency, East Kalimantan. 3, 88-98.

Tawakal, I. (2018). The relationship between parents' socioeconomic status and learning motivation with student achievement in SMK Dinamika Pembangunan 1 Jakarta. State University of Jakarta,

Tyng, CM, Amin, HU, Saad, MN, \& Malik, AS (2017). The influences of emotion on learning and memory. 8, 1454.

Umam, MKJA-HJKDS (2020). Dynamics of quality management from Islamic education perspective. 8 (1), $61-74$.

Weiner, B. (2018). The legacy of an attribution approach to motivation and emotion: A no-crisis zone. 4 (1), 4.

Wibowo, KP, \& Marzuki, M. (2015). The application of the media-assisted make a match model is to increase motivation and social studies learning outcomes. 2 (2), 158-169. 
Wilhelms, M.-P., Henkel, S., \& Falk, T. (2017). To earn is not enough: A means-end analysis to uncover peerproviders' participation motives in peer-to-peer carsharing. 125, 38-47.

Yuliani, K., \& Saragih, S. (2015). The development of learning devices based guided discovery model to improve understanding concept and critical thinking mathematically ability of students at islamic junior high school of medan. 6 (24), 116-128.

Zhang, W., Wang, Y., Yang, L., \& Wang, C. (2020). Suspending classes without stopping learning: China's education emergency management policy in the COVID-19 outbreak. In: Multidisciplinary digital publishing institute. 